\title{
Biosphere reserves and their contribution to sustainable development ${ }^{1}$
}

\author{
A value-chain analysis in the Rhön Biosphere Reserve, Germany
}

\begin{abstract}
The regional labeling scheme Dachmarke Rhön is an approach of the Rhön Biosphere Reserve to foster sustainable economic development through the intensification of regional value chains. The study compares the members of the Dachmarke Rhön with a random sample, both consisting of small rural enterprises in the economic sectors of tourism and food processing. Based on face-to-face interviews with 99 managers, a comparison of the two groups regarding their integration into regional value chains is elaborated: the two groups mainly coincide with regard to the reasons for choosing local suppliers. However, members of the Dachmarke Rhön are putting more emphasis on regional buying and the relationship to their suppliers. The share of total value added within the enterprises is higher in the random sample. This on the other hand explains higher expenses for supplies and a lower direct regional economic impact within the group of enterprises of the Dachmarke Rhön. Nevertheless the analysis shows, that the expenses for buying goods stay to a greater proportion within the region and facilitate a more diverse economic structure. Thus indirect regional economic effects are maximized fostering multifunctionality at the same time. The Dachmarke Rhön therefore can be seen as a market-based tool for fostering sustainable economic development, although the need for improvement regarding logistics and education for sustainable development exists.
\end{abstract}

Keywords: Biosphere reserve, regional economic circulation, value chain, sustainable regional development, regional labeling, food processing, tourism

\section{Introduction}

Within the UNESCO program Man and Biosphere $(\mathrm{MaB})$ the concept of biosphere reserves (BR), an innovative form of protected areas, was elaborated to achieve the superordinate aim of sustainability; it is based on three functions, namely (1) conserving ecosystems and genetic resources, (2) supporting research, monitoring and education and (3) fostering sustainable development. The Seville Strategy released in 1996 had a major impact on the international strategic orientation of BR (UNESCO 1996). Sustainable development gained tremendous importance within the weighting of the three main goals of BR, which reinforced the role of $\mathrm{BR}$ as important places of action for concerns discussed within the Agenda 21 and the Rio Conference (UNESCO 1996, 1). The apparent contradiction between protection and development is believed to be surmounted with the help of a zoning model (UNESCO 1996, 4). The development and buffer zone, surrounding the core zones of nature conservation, are the places for developing and testing innovative approaches to foster a sustainable regional economy. In this context Austria, Germany and Switzerland, as important countries within the development of the $\mathrm{MaB}$ program in Europe, have independent national strategies to achieve the general goal of sustainable development. Nevertheless, the strengthening of the regional economy through diversification and the intensification of regional value chains is a common strategic element in all three countries (Deutsches MaB-Nationalkomitee 2007, 22 f.; Österreichisches MaB-Nationalkomitee 2006).

The expected economic impact of these implementations can be seen as an additional value added which goes beyond the considerations of MAYER/JoB (2014). Although the intensification of regional value chains is widely seen as a tool to foster economic development in peripheral regions, quantitative analysis regarding regional value chains and regional economic cycles are not evident for none of the German BR. The same holds true for regional marketing projects and the determination of total value added of such projects as well as its comparison to conven- 
tional economic relationships (KULLMANN 2007, 131). There is a general lack of quantitative data to measure "regionality" of products and economic connections and therefore to weigh up the pros and cons (ERMANN 2005, 294). The present study is a first attempt to fill this research gap and gives hints concerning the still existing questions in how far BR can match the expectations and how are they performing (STOLL-KLEEMANN/ Jов 2008, 88). A short overview about the national frameworks and implementation strategies shows the framing conditions for stakeholders in BR. Furthermore, this article analyses regional labelling schemes and local buying in rural enterprises in the nexus of economic development. The Dachmarke Rhön (DMR), a role model for a successful implementation activity in BR, is examined in comparison to a sample group, to show the economic impact of local buying in rural enterprises and its contribution to economic development. Therefore the case study compares the two groups of enterprises regarding reasons for regional buying, turnover and value added, as well as the integration of the enterprises into the structural and geographic patterns of supply chains.

\section{Implementation of the Seville Strategy}

The Seville Strategy proposes diverse guiding principles for an international, national and regional scale to achieve best results in terms of the three paramount goals of BR. Due to the different circumstances in particular countries, the international strategy recommendations are to be understood as guidelines, which have to be adapted to the local situation (UNESCO 1996, 6). There are usually MaB National Committees with representatives from diverse disciplines, which have the task to specify and implement the $\mathrm{MaB}$ program on a national scale. In 1996 the German MaB National Committee developed the national guidelines for the German BR, which were revised and published in 2007. The designation of new BR and the development of existing ones are monitored with the help of this set of criteria.

Goal II within the Seville Strategy specifies approaches to sustainable development. Activities, compatible with the demand for conservation, are to be strengthened by transfer of technologies that incorporate traditional knowledge and bottom-up approaches. On the individual scale of the BR, natural products and services are to be probed and used to establish environmentally acceptable and economically sustainable income opportunities for the local population. Furthermore, an advisory system, consisting of local stakeholders from different fields (economy, social, environment etc.), should be established and topics like agriculture, forestry and tourism should be discussed (UNESCO 1996, 8). A substantial part of the strategy for sustainable economic development is the task to develop the best possible closed material cycles and their connection to natural cycles. Likewise regional economic cycles should be established to foster typical regional craft and trade. For the service sector environmentally sound products should be promoted with the help of suitable measures like local brands and quality systems (Deutsches MaB-Nationalkomitee 2007, 22 f.).

In Austria a corresponding implementation of the Seville Strategy is realized. The Austrian criteria catalogue of the MaB National Committee summarizes sustainable economic development under the article of "Planning and Development". It proposes that all economic sectors (especially agriculture, forestry, energy sector and waste management) should implement sustainability as a paramount objective. Regional economic cycles and value chains are to be established and intensified to retrieve a greater economic effect for the region and simultaneously strengthen the acceptance for the BR within the local population (Österreichisches MaB-Nationalkomitee 2006, 4).

In Switzerland there is no such MaB National Committee or an official set of criteria. To apply for the designation of a BR, the concerning region has to meet the requirements of a "Regionaler Naturpark" (nature park) (BAFU 2013). The requirements are written down in the "Regulation for parks with national importance". It talks about the "Strengthening of sustainable economy" and specifies that local resources have to be used in an environmentally-compatible way. The regional processing and marketing of products, generated within the park boundaries, have to be fostered. Additionally, services in tourism and environmental education should be strengthened (PÄV 2007).

In order to implement the German criteria and finally come closer to the overall aim of sustainable development, there are regional frameworks, considering the individual circumstances on the local scale. In general, these concepts in- 
clude a comprehensive inventory of the ecological, social and economic situation of the region to reveal the strengths and weaknesses and to specify guiding principles for the BR (e.g. the regional frameworks of the BR Schaalsee and Rhön) (GreBe/BAUERnschmitT 1995; Amt für das Biosphärenreservat Schaalsee 2004). Development goals are important to reconcile environmental conservation with socio-economic development. A broadly-accepted framework to institutionalize the interaction of stakeholders, negotiate interests, mitigate conflicts and enhance local participation can be regarded essential for good governance and regional development (BRENNER/JoB 2011, 14).

In Austria similar regional frameworks exist in the BR Wienerwald and Großes Walsertal (BPM Regio Großes Walsertal 2011; Biosphärenpark Wienerwald Management GmbH 2012). The remaining four BR Lobau, Neusiedler See, Gurgler Kamm and Gossenköllesee were established without the participation of the local population and represent protected areas with a focus on segregated conservation. All four BR being established in 1977, the Seville Strategy doesn't play a major role. Until now the zoning concept is missing and the areas are too small to foster sustainable economic development (LANGE 2008, 4). In Switzerland regional guidelines exist for both BR (UNESCO Biosphäre Entlebuch o. J.; Biosfera Val Müstair - Parc Naziunal 2004).

A successful example for the implementation of economic development in accordance with the aspect of protecting ecological rich cultural landscape is the project "Oberlausitzer Bio-Karpfen", initiated through the management of the BR Oberlausitzer Heide- und Teichlandschaft. A cooperation between the BR management and local businesses that were in favor of organic aquaculture (e.g. no use of genetically altered fodder, limiting the production) was able to present the first, legally certified (by the EU), organic cultured carp in 2009. The project not only accomplished a more sustainable use of natural resources, but also generated higher profits for the producers through qualitative high standard regional products (DRL 2010, 56).

This overview from a national to a regional level has shown that the intensification of regional economic collaboration is one important strategy for BR in central Europe. The examined national strategies include the intensification of regional value chains and product cycles to achieve a greater economic impact. An important part within this strategy is the marketing of local products and services.

\section{Theoretical background}

There is an impressive growth of local and regional brands and marketing schemes in the European market (VOTH 2003; BARHAM 2003; ILBERY/MAYE 2007; ERMANN 2009). Globalization, new trends in customer demand and the rising competition between regions are few factors, which are leading to higher requirements for the management of such local brands. These factors are particularly challenging for rural and peripheral regions as the framing conditions are less favorable. Rural regions are looking for new opportunities for their positioning on the market and at the same time they are trying to develop new endogenous potentials. With regard to the European BR, the establishment and promotion of local brands and quality systems are a very important strategy to foster regional development. Thus the orientation of marketing schemes towards all three dimensions of sustainability becomes crucial (Deutsches MaB-Nationalkomitee 2007, 23).

The most common implementation of these marketing initiatives is the use of "labels of origin" that are directly associated with the place of production. The marketing and development of foods from a certain region enhances the image of the region and can be seen as an innovative process for securing and developing new income (VоTH 2003). A strong growth of numbers of these schemes, that are based on product marketing, labelling and accreditation, advertising particular production processes, specific agricultural and craft products or regions, has occurred in Europe since the beginning of 1990s (ILBERY/ MAYE 2007, 508; BARHAM 2003, 137). ERMANN (2009) observes this trend also in Germany and describes the high diversity in the implementation of such initiatives, which is not only based on the products and production processes but also on the purpose and the stakeholders.

Literature, specific to this context, often refers to the term alternative food networks, which is a broad embracing term to cover newly emerging networks of producers, consumers, and other actors that embody alternatives to the more standardized industrial mode of food supply 
(RENTING et al. 2003, 394). Alternative food networks, by their nature, employ different social constructions and equations with ecology, locality, region, quality convention and consumer cultures. As such, a major theoretical and empirical task is to explore how they evolve and contribute, in different ways, to rural development. "We should not be fooled into thinking of localness, naturalness, and embeddedness as sufficient in themselves; rather, we must show how these qualities come to be asserted and negotiated in food supply chains" (MURDOCH et al. 2000, 122). Within this context, there also exists the concept of the short food supply chain. The short food supply chain is more specific than alternative food networks, but is often used interchangeably. It covers the interrelations and spatial connections between actors who are directly involved in the production, processing, distribution, and consumption of new food products (Renting et al. 2003, 394). All these systems operate in part at least on the principle that the more embedded a product gets, the scarcer it becomes in the market. A central point to the existence of alternative food networks and short food supply chains "is their capacity to resocialise or respatialise food, thereby allowing the consumers to make new value judgments about the relative desirability of foods on the basis of their own knowledge, experience, or perceived imagery. [...] Notable here are the additional identifiers which link price with quality criteria and the construction of quality." (MARSDEN et al. 2000, 425).

The emergence of these agriculture- and foodbased schemes are situated within the context of a more general transition in rural economies, characterized by some, as the shift from a "productivist" to a "postproductivist" food regime (ILBERY/Bowler 1998; NiLes/RofF 2008). The reasons for this change, which is also a response on the fracture between consumers and the traditional producer of food, are complex, multiple and well described by Niles/Roff (2008). According to VAN DER PlOEG et al. (2000), such shift is a new "rural development paradigm". In this context the question arises, whether rural development represents a qualitatively different development model (VAN DER PloEg/Renting 2004) or whether it can be understood within the framework of modernization (further development of multifunctionality and endogenous development) (GOODMAN 2004). DARNHOFER $(2005,309)$ concludes in this context that "it is less an either/or choice, but rather the two poles of a continuum" and VAN DER PloEg et al. (2000, 391) stress that the term rural development is widely used, "but there is still no comprehensive and agreed-upon definition of it". It can be added that the limited view on agriculture is also unjustified and leaves out other important stakeholders in rural areas.

The term "rural development" embraces a lot of different areas of activity such as the production of high quality and local products, nature conservation, and landscape management, agro-tourism and short supply chains. These rearrangements are happening in a competitive way, where participants try to unlock new potentials and to access new resource arenas. The important link between all these activities is the readjustment and complete change of resource use within enterprises and between rural stakeholders. Multidimensionality, multifunctionality and high degree of integration characterize almost all new activities. The multi-dimensions of these activities is in line with more recent experience, which suggests that a strict segregation of such different functions as living, production, recreation and nature conservation can hardly be realized. Instead new forms of multifunctionality (re-)emerge and these can result in the construction of a new resource base at regional level (KNICKEL/RENTING 2000), which has a great parallelism with the ideas behind the BR concept. To make an even broader connection to BR, local food systems also have synergies with a European model of agricultural multifunctionality (Ilbery/Maye 2007; HuYLENBROECK/ Durand 2003; Goodman 2004). As PotTer/ BuRNEY $(2002,35)$ remark "agriculture is multifunctional, producing not only food but also sustaining rural landscapes, protecting biodiversity, generating employment and contributing to the viability of rural areas". This concept is endangered through the dynamic expansion of renewable energies and its consequences for the landscape. Especially in rural or protected areas that are ecologically valuable and attractive to tourism, the consequences for the regional value added are seen with skepticism (MEgERLE 2013, 161). The marketing labels on the other hand can be seen as a proactive market-based instrument to shape a rural region, sustain cultural landscapes and biodiversity. To gain these effects and to have an economic impact for the region, the environmentally sustainable food production must be marketable and, to put it other way round, the incentive for food producers to manage the environment positively 
comes directly through the market (BULLER/ MORRIS 2004).

The set-up of an ambitious regional strategy or plan with one common idea can help single stakeholders to gain benefits from achieving these goals and to change the way of resource distribution. In addition, those different activities of stakeholders can lead to economic development and new forms of regional income. In turn, the results of this collective action become a new resource base for future rural development activities (KNICKEL/RENTING 2000, 520).

Rural development practices are based on synergy between different fields of activity and between different levels and actors. In this respect VAN DER Ploeg / Renting $(2000,534)$ refer to the occurrence of "clusters of compatible and mutually reinforcing activities". A common cluster is nature conservation, farm tourism, quality production and direct marketing. These examples indicate that multifunctionality in many respects is a necessary precondition for the occurrence of synergy. Multifunctionality relates to the combination of resources or goods such as products, services available both at the farm-level and beyond. A combination of new rural development activities and on-going activities may lead to an upgrading or revalorization of existing resources and activities, and can result in over-all cost reductions. There are indications that the potential for synergies also increases with the complexity of farming systems due to the capacity e.g. to maintain local breeds and associated endogenous farming practices, because they are embedded in a wider network (KNICKEL/RENTING 2000, 522; Ventura/Milone 2000).

From a regional view and in the context of a broad and holistic regional development, the exclusive analysis of agriculture and food is not enough, thus requiring other sectors and services to be included into the picture. Of special importance is rural tourism, which is deeply dependent on issues like landscape, built and living culture (language, traditions, heritage) and food, and therefore can lead again to a high grade of connectedness between different local stakeholders. In addition, Sims $(2009,322)$ argues that local food has the potential to enhance the visitor experience by connecting consumers to the region and its perceived culture and heritage. Local foods are considered to be "[...] 'iconic' products that capture the 'typical' nature of a place" and thereby promoting authenticity. These foods can help to distinguish a destination from another, to expand recognition of the region and to generate visitor numbers and expenses. On the one hand, the promotion and consumption leads to benefits for the local economy via multiplier effects, and on the other hand, ensures self-sustaining by strengthening the local potentials and actors (TORRES 2002). A key to better understanding these diverse effects on several levels and stakeholders is to examine changes in resource use (input flows and output flows) in relation to the distribution and use of additionally generated incomes.

\section{Methodological design}

As BätZing/ERmanN (2001, 117) point out, there is a lack of studies about economic interrelations on a local level. Newer approaches in economic geography like industrial districts, production networks and creative milieus focus on these connections, but the kind of links and the sectors are normally not connected to regional economic cycles and regional development of rural areas. In order to look at the benefits of the above mentioned rural development practices, this article analyzes the buying decisions of small businesses in a rural surrounding with respect to economic impacts and its spatial linkages as the starting point of a regional value chain. As KNICKel/ReNTING (2000, 513) observe, "Any analysis must take into account the new interrelations developing at different levels between farming, the rural areas and society at large. If new activities are an expression of a reconfiguration of the use of rural resources, then changes in resource use can provide some important initial clues of relevant interfaces." In this regard, the analysis of the entire chain of productive activities, often referred to as supply chain, value chain or commodity chain is a suitable tool for further insights. A chain maps the vertical sequence of events leading to the delivery, consumption and maintenance of goods and service (STURGEON 2001). This perspective opens the view on different aspects of the process of value generation and it takes the governance of these chains into account: how chains are organized and managed. "The connections, or 'linkages' between firms and subsidiaries operating in and among different locations can provide the comparative insight, that can help us to judge, however, imperfectly, the impacts that local and national institutions have on the process of economic development." (STURGEON 2001, 9 f.). 
In tourism the use of value chains is less prevalent and mostly focused on an international level, where global governance structures and impacts are examined, e.g. SchAmp (2007) shows the connection between the tourism demand and governance structures of the global north and the impacts on a local level in faraway places of the world. Yet, the concept of the value chain is seldom used to analyze the diverse tourism structures in Germany on a local level.

The following methodological approach was used to analyze local supply chains: Two different groups of enterprises were interviewed with structured standardized interviews. The survey design of two groups was needed to compare results and to get a deeper insight into the characteristics of buying patterns in a rural area. Group 1 consists exclusively of enterprises belonging to the DMR and are obliged to the aims of the BR, the Seville Strategy and the corresponding regional framework. Group 2 on the contrary, is designed to be a control group. These enterprises were randomly chosen from a regional business database. ${ }^{2}$ In the following the buying patterns in tourism and traditional food processing enterprises are evaluated and a deeper insight into their economic structures is given. Since data required for further explorations is very diverse and sensitive, 99 personal interviews with an average duration between 40 and 90 minutes were conducted with managers and enterprise owners. The survey of Group 1 reached a very high response rate of $92,3 \%$ in food processing and $79,7 \%$ in tourism enterprises. This positive feedback can be explained by a high interest of the DMR members to improve the performance of the marketing scheme. In Group 2 on the other hand, only $12 \%$ of the contacted enterprises in food processing and tourism were willing to participate. Even though, the rate of return is very different in both sample groups, the willingness to answer sensitive questions was similar in both groups.

Both groups were asked questions concerning important economic parameters such as business type, turnover and employment. In addition, the enterprises also were questioned about their internal production processes to analyze the cost structure of enterprises (see Fig. 1). The ratio between total value added (TVA) and turnover is normally used on a regional level as a Keynesian multiplier to estimate the direct regional income. Thus the results are a rare dataset of re- gional economic multipliers in rural Germany. Most data sources in this context are based on a national level due to the great efforts which are needed to gather data (e. g. MASCHKE 2007; Destatis 2011). Finally, a complete list of suppliers with their percentage in terms of turnover and the reasons for these linkages were collected. Data was processed using different database management systems like MS Access, SPSS and GIS technology to gain an overview about the spatial distribution and its regional impact. The spatial analysis of supply chains is based on the regional definition.

Fig. 1: Total value added and internal production patterns

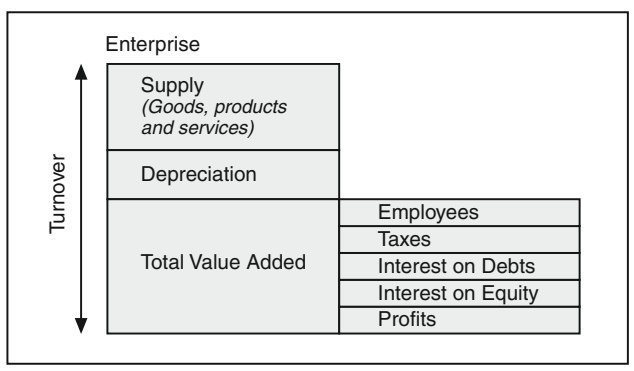

Source: RÜTTER et al. 1996, 10

\section{Case study: Rhön Biosphere Reserve and the Dachmarke Rhön}

The case study area Rhön is a low mountain range area, situated in central Germany at the border triangle of Bavaria, Hesse and Thuringia. The region can be described as a rural and peripheral area with a low population density (Fig. 2). Until 1990, the region was divided by the "Iron Curtain", and shortly after the reunion, the area was recognized by the UNESCO as a BR to conserve the landscape and foster sustainable regional development. The natural environment is the main unifying factor for the Rhön. The cultural landscapes, famous for their rich ecological diversity, are the result of a long period of agriculture (KNICKEL 2001).

The three BR administrations, together with the regional stakeholders (e. g. districts, municipalities, enterprises), are working on an integrative management plan to set long-term goals and an evolutionary framework for the region (GREBE/ BAUERNSCHMITT 1995; BBR 2012). One paramount objective of this plan is the professional 
Fig. 2: Rhön Biosphere Reserve and the members of Dachmarke Rhön

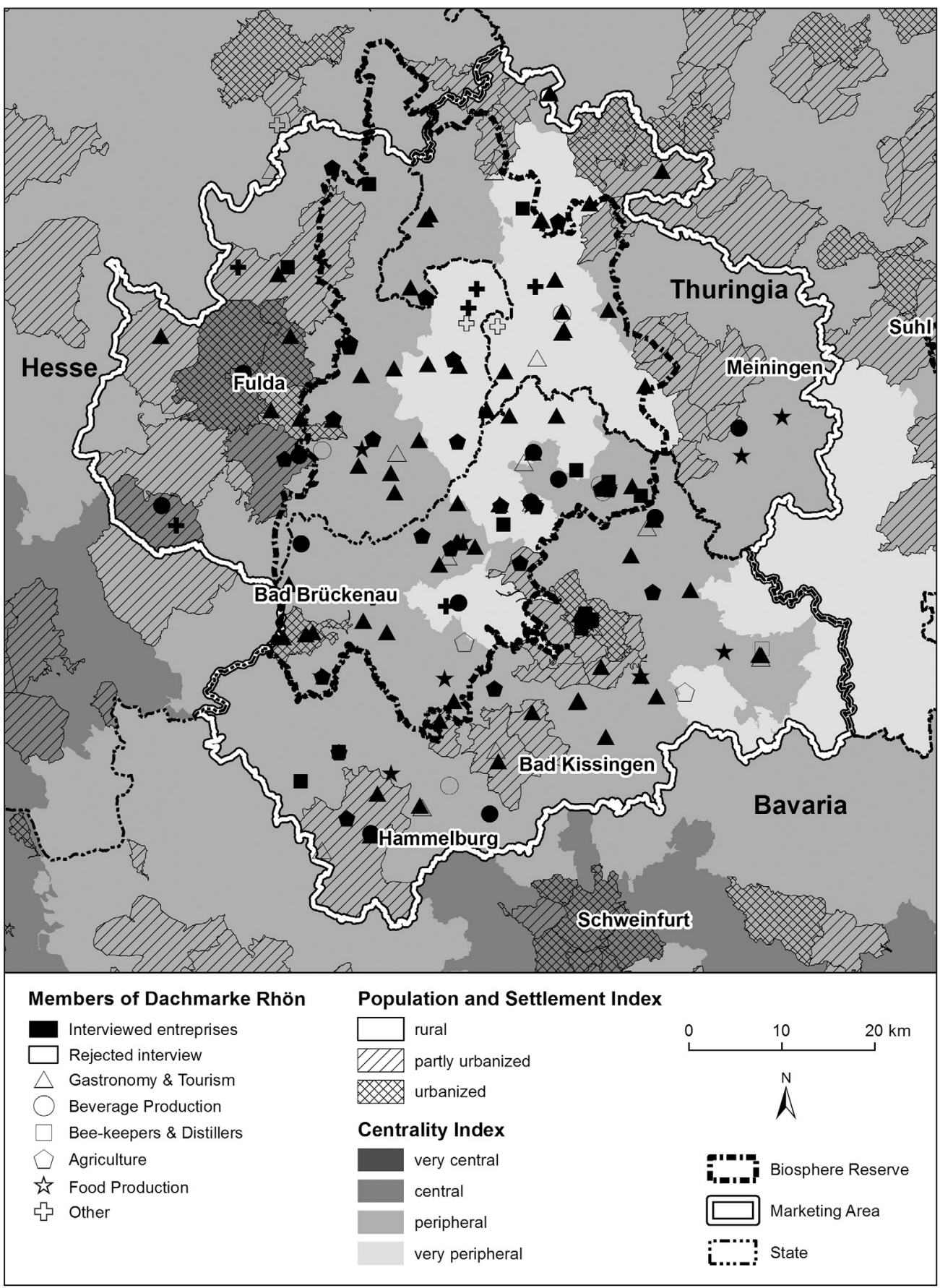

Source: BBSR 2011; Dachmarke Rhön 2011; draft and cartography: Felix Kraus, JMU Würzburg 2012 
marketing of the region, to shape internal and external relationships for enhancing collaboration within this area. The marketing strategy also includes the formation of a unified tourism destination, to attract new visitors and better cope with new demands and trends in tourism.

Due to the management plan, regional institutions within Rhön Biosphere Reserve try to foster endogenous potentials by strengthening quality products and services. The implementation and re-shaping of local supply chains with the idea to improve the local circular flow of goods, products, services and finances is one of the objectives which can enhance new forms of resource use and regional income. Not only the implementation of these new structures, but also the quality management with a strong focus on controlling is part of the strategy. The establishment of the DMR as an integrative management and marketing platform is the main instrument to achieve the above mentioned goals. The DMR is to be seen as a model to newly negotiate the use of regional resources between development and landscape conservation. Since the start of the BR, its foundation has been a huge step in a row of several smaller projects in the context of sustainable development. The DMR is on the one hand a management platform which tries to bring together all stakeholders of the region, and on the other hand an umbrella brand which is responsible for the marketing and promotion of the region and specific products of associated members. After several approaches of the biosphere reserve to establish a network of partner enterprises, the DMR was founded in 2007 as a limited company. It has a professional management and consists of over 200 partners (BRR 2012).

The DMR is based on "relations of spatial proximity", where products are sold within the region of production and consumers (e.g. inhabitants and tourists) are made aware of the "local" nature of the product at the point of retail. The quality definitions of the products are based on regional, artisanal and ecological characteristics. This shows that the DMR is a hybrid brand where different and not only one product characteristic are combined (RENTING et al. 2003). Its direct link to the conservation of cultural landscapes can be seen as a rare approach in Europe. The DMR is working as an umbrella brand in several branches and most associated enterprises are based in agriculture, food and beverage production, gastronomy and tourism (Fig. 2). It makes use of several different labels, which are adapted to the needs of different products and services. The product labels are strictly separated between organic and conventional production of food and products. They are promoting the locality of goods with specific production processes. These processes are well defined and standardized to shorten literally and figuratively the distance between production and consumption. At the same time the DMR is involved in tourism destination management and tries to establish the idea of local products and local buying in tourism enterprises. Based on the amount of use of local products, the participating tourism enterprises can earn three gradual different labels. The regional definition of "spatial proximity" of the marketing scheme is the marketing area to achieve the local character of goods and services (Fig. 2). The marketing area consists of the five adjoining administrative districts and thus exceeds the actual size of the BR. The delimitation of the marketing area is supposed to form a greater tourism destination and to reach a critical size to enhance market awareness.

\section{Results}

The enterprises under exploration are divided into two groups. Important parameters of the enterprises are shown in Fig. 3. The left side shows the characteristics of tourism enterprises for the DMR sample $(\mathrm{n}=63)$ and the random sample $(n=36)$. The members of the DMR are on average substantially larger businesses than the others in terms of employment and turnover. All in all, both samples show that they predominantly consist of micro-enterprises. Tourism in the Rhön Biosphere Reserve is based on small businesses with a small capacity for strategic management. The comparison of both groups makes clear that most members of the DMR are offering gastronomy and rooms, and on the other side the random sample consists of more businesses which are having rooms only. The two groups of food processing enterprises are smaller $(n=10$ and $n=11$ ), but the structures of the groups are quite similar. As well as in tourism it can be put down that all enterprises can be described as micro, but the members of the DMR are again significantly larger than the random sample. The regional setting together with structural differences between the two groups and the partly small sample sizes should be kept in mind during the further exploration. 
Fig. 3: Structure of enterprises in the Biosphere reserve

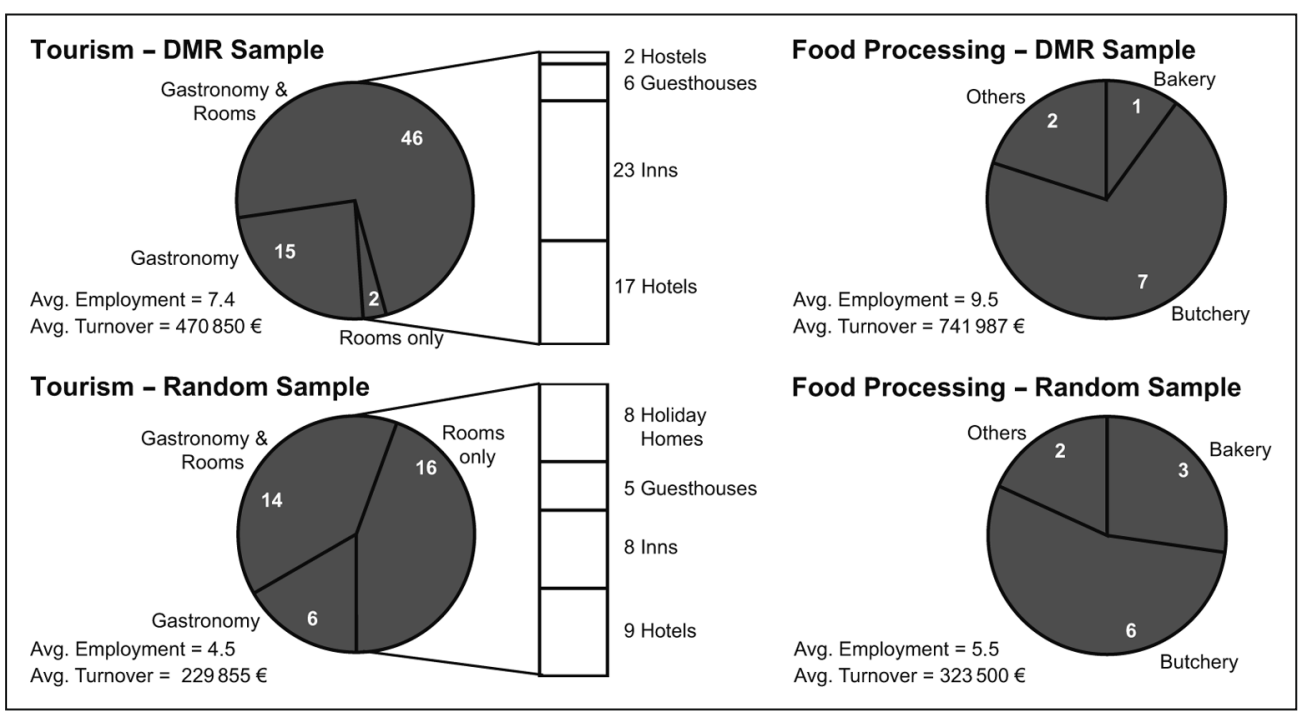

Source: own design and research

\section{Local buying in enterprises}

The DMR has several goals to foster endogenous potentials within the BR, and one paramount objective is promoting local buying in enterprises. In this regard it seems insightful to explore the management rationales of the participating enterprises which are the base for local buying and the importance of such actions. Rationales related to "regional economic impact" are most important for all enterprises. Most managers are buying local, because they see a connection between local buying and improving or conserving the regional economy. Individual statements behind that term are e.g. "creation of jobs", "fostering economic circles", "keep money in the region". Furthermore, it seems clear that the direct relationship to suppliers has a high value for most enterprises. The management of rural enterprises state that e.g. reliability, flexibility, personal connections, transparency are very important and these characteristics are easier to be found in local relationships. Other reasons for local buying stated are e.g. "short ways" for saving miles, "quality" in terms of the characteristics of goods and better "marketing" possibilities. It can be found that "regional economic impact", "relationship to supplier", "marketing", "mutuality" and "philosophy" reach considerably higher percentages in the DMR group than in the random sample.
The question about the importance of such "short" business relationships for the management shows that the idea of local buying is widely spread in the region. DMR enterprises reach a higher level of importance. $90 \%$ of the managers think that local buying is important or very important, but most other enterprises state also a high value of $80 \%$.

\section{Total value added and supply}

The buying decision and selection of suppliers is a strategic basis and success factor for the production of goods and services within an enterprise. Businesses are dependent on high quality, good prices and low transaction costs. Additionally there is a great potential e.g. for marketing, innovation and efficiency improvements in the management of supply chains. Yet, the buying decisions of enterprises can also be seen as a substantial factor for the restructuring and reshaping of economic processes to a more sustainable regional economy and overall development. Due to the high expenditures for inputs in the production process it can make a substantial change in terms of regional economic impacts and for the enterprises, too.

Tab. 1 shows that the average percentage of expenditures on supply in relation to turnover 
can vary between $35.8 \%$ and $53.8 \%$ within the sample. These numbers are highly dependent on the sector and their specific resource needs, but in general it shows the potential for high regional impacts. The comparison between both sample groups shows the tendency that the concept and aims of the DMR is resulting in higher expenditures on supply. The analysis of variance does not generate significant statistical evidence for the difference due to sample size and heterogeneity in data, but still the average expenditures are higher in both groups related to the DMR. Additionally and consequently these results lead to lower percentages of TVA in the DMR sample (Fig. 1). Again these results are not statistical significant, but it shows the integrity of data. Lower percentages of total value added means that less turnover is distributed to wages, taxes, interest rates and profits within the enterprise. From a regional and aggregated view, the lowering of TVA in businesses leads to a lower direct economic multiplier and thus less direct economic impact.

Tab. 1: Supply and total value added

\begin{tabular}{llcc} 
Sector & Sample & $\begin{array}{c}\text { Avg. TVA } \\
\text { in \% of turnover }\end{array}$ & $\begin{array}{c}\text { Avg. supply } \\
\text { in of turnover }\end{array}$ \\
\hline \multirow{2}{*}{ Tourism } & DMR & $53.9(\mathrm{n}=42)$ & $39.0(\mathrm{n}=24)$ \\
& Random & $57.2(\mathrm{n}=31)$ & $35.8(\mathrm{n}=29)$ \\
\hline Food pro- & DMR & $36.2(\mathrm{n}=10)$ & $53.8(\mathrm{n}=10)$ \\
cessing & Random & $54.4 \quad(\mathrm{n}=9)$ & $42.9 \quad(\mathrm{n}=9)$ \\
\hline
\end{tabular}

Source: own design and research

\section{Supply chain analysis}

The connection between supply chains and regional economic development needs deeper exploration to understand the mechanisms within the enterprises of marketing initiatives like the DMR. The number of connections between tourism and food processing businesses and related suppliers (like trade, agriculture and manufacturing) are displayed in Tab. 2. The differentiation between the DMR and the random sample shows differences in structure and spatial distribution. The number of supply relationships of tourism enterprises demonstrates that the random sample is more dependent on trade, $53.1 \%$ of all connections, and has less links to other sectors like agriculture and manufacturing. Additionally the spatial analysis shows that the distribution of suppliers within and outside the region is not different. In total, approximately $72 \%$ of the connections to suppliers are within the marketing area in both groups. Exploring just the numbers of connections, there is almost no indication, that the DMR is improving the situation of local buying in tourism. The DMR changes more the structure of buying away from trade to agriculture and manufacturing. These connections can be seen as a change to greater multifunctionality and a greater network between regional stakeholders.

The food processing enterprises show different structures. The enterprises of the DMR rely more on other food manufacturing suppliers $(51.8 \%)$, whereas the random sample has considerably more connections to trade $(51.2 \%)$.

Tab. 2: Number of supply relationships (in \%)

\begin{tabular}{|c|c|c|c|c|c|c|c|c|c|c|c|}
\hline & \multicolumn{5}{|c|}{ DMR Sample } & \multicolumn{5}{|c|}{ Random Sample } \\
\hline & & $\begin{array}{l}\text { Market- } \\
\text { ing area }\end{array}$ & $\begin{array}{l}\text { Outside } \\
\text { of region }\end{array}$ & $N / S$ & Sum & $\begin{array}{l}\% \text { of } \\
\text { total }\end{array}$ & $\begin{array}{l}\text { Market- } \\
\text { ing area }\end{array}$ & $\begin{array}{l}\text { Outside } \\
\text { of region }\end{array}$ & $N / S$ & Sum & $\begin{array}{l}\% \text { of } \\
\text { total }\end{array}$ \\
\hline \multirow{5}{*}{$\begin{array}{l}\tilde{n} \\
\stackrel{n}{\Xi} \\
\stackrel{0}{0}\end{array}$} & Trade & 64.6 & 32.3 & 3.1 & 100 & 26.2 & 68.1 & 26.5 & 5.3 & 100 & 53.1 \\
\hline & Agriculture & 82.8 & 10.9 & 6.3 & 100 & 26.4 & 84.6 & 7.7 & 7.7 & 100 & 6.1 \\
\hline & Other & 54.2 & 16.7 & 29.2 & 100 & 4.9 & 66.7 & 25.0 & 8.3 & 100 & 5.6 \\
\hline & Manufacturing & 72.3 & 23.3 & 4.4 & 100 & 42.5 & 77.3 & 17.3 & 5.3 & 100 & 35.2 \\
\hline & Total & 72.2 & 22.1 & 5.8 & 100 & $\mathrm{n}=485$ & 72.3 & 22.1 & 5.6 & 100 & $\mathrm{n}=213$ \\
\hline \multirow{5}{*}{ 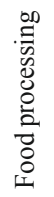 } & Trade & 65.2 & 30.4 & 4.3 & 100 & 27.7 & 52.4 & 42.9 & 4.8 & 100 & 51.2 \\
\hline & Agriculture & 84.6 & 0.0 & 15.4 & 100 & 15.7 & 100 & 0.0 & 0.0 & 100 & 9.8 \\
\hline & Other & 0.0 & 50.0 & 50.0 & 100 & 4.8 & 0.0 & 100.0 & 0.0 & 100 & 1.2 \\
\hline & Manufacturing & 37.2 & 53.5 & 9.3 & 100 & 51.8 & 58.1 & 41.9 & 0.0 & 100 & 37.8 \\
\hline & Total & 50.6 & 38.6 & 10.8 & 100 & $\mathrm{n}=83$ & 58.5 & 39.0 & 2.4 & 100 & $\mathrm{n}=82$ \\
\hline
\end{tabular}

Source: own design and research 
Furthermore, the DMR sample gives reasons to have more direct contact to agriculture $(15 \%)$. The geographical distribution of these relationships is quite diverse, and it becomes clear that the DMR members have more connections with trade businesses within the marketing area, but have less links to the food manufacturer within the region than the random sample. All in all, we see a lesser dependency on trade within the DMR sample, but the spatial distribution of the number of connections within the marketing area is not higher than in the random sample.

From a regional development perspective the numbers of links between lead firms and suppliers are an important indicator for the understanding of the structure of a rural economy, but more intriguing is the analysis of turnover, which is distributed within the region or outside. The monetary distribution of supply from the lead firms to the suppliers is shown in Fig. 4. The analysis reveals substantial differences in com- parison to Tab. 2. In tourism enterprises of the DMR $77 \%$ of the money for supply stays within the region compared to $63.5 \%$ from the random sample. This ratio shows that the DMR members are having similar supply structure as the sample group in terms of numbers, but in terms of money spent for supply these businesses help to keep more money within the marketing area. Furthermore, the distribution between the different supply sectors is significantly different. The random sample has a very high dependency on trade with $74.8 \%$ directly connected to this sector. The DMR group gets less than $50 \%$ of their supply from this branch. Thus, more manufacturing and especially agricultural enterprises are benefiting from these monetary links, which results in a higher regional impact due to the higher total value added in those segments compared to trade.

The empirical sample is much smaller in the food processing sector and thus inaccuracies within the data have a bigger impact. The follow-

Fig. 4: Monetary distribution of supply chains (\%)

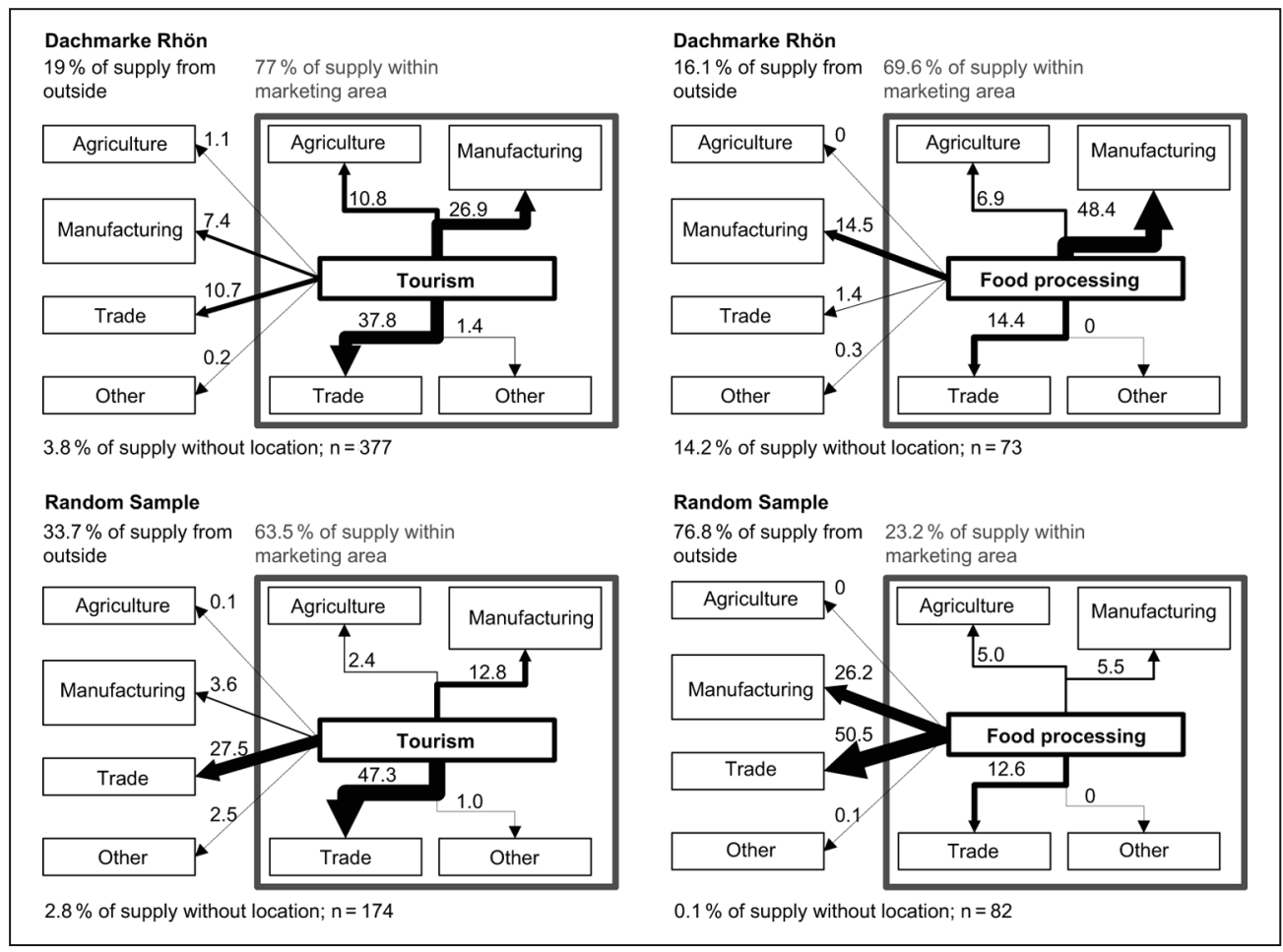

Source: own design and research 
ing results should be interpreted carefully, but nevertheless, there are even more distinct spatial and structural differences. The comparison of the ratios between inner- and outer-regional buying shows that food processing enterprises of the DMR spent almost $70 \%$ of their money on supply within the region, compared with only $23.3 \%$ in the random sample. Food processing suppliers within the Rhön are strongly benefiting from the monetary flows triggered by DMR members.

Furthermore, two effects can be seen within the data. First, there is a higher amount of money spent within the marketing area of the DMR by members. This effect leads to higher indirect economic impacts in terms of regional development. Secondly, we observe a restructuring of supply chains towards a greater multifunctionality and a lesser dependency on trade.

In the next step the analysis takes a deeper look at the reasons and rationales for single supply relations (Fig. 5). The focus is on tourism as sample size allows a more reliable analysis. The supply chains from tourism to trade have such a great importance due to the high expenditures, which reach $48.5 \%$ in the DMR and $74.8 \%$ in the random sample of total supply. Furthermore, the different management reasons of tourism enterprises to buy at agricultural businesses are analyzed, due to the high importance of agriculture for the conservation of cultural landscapes. Obviously, the product itself with its characteristics and quality definitions is most important for managers of both groups in supply chains to trade and agriculture.

Relationships between tourism and trade show that the second most important reason for the choice of suppliers is very different between both sample groups. On the one hand DMR members believe that the personal "relationship" to suppliers is the second most influencing factor. These enterprises state e.g. that personal contact is giving them more flexibility, transparency, better contracts and insight into pricing. In addition with the statement of "relationship characteristics" (23\%), which consists of terms like "honesty", "transparency" or "reliability" and which ranks third in the DMR group, the broad category around relationship becomes the most important influence factor for supply chains for members of the DMR.
Fig. 5: Reasons for single supply relations

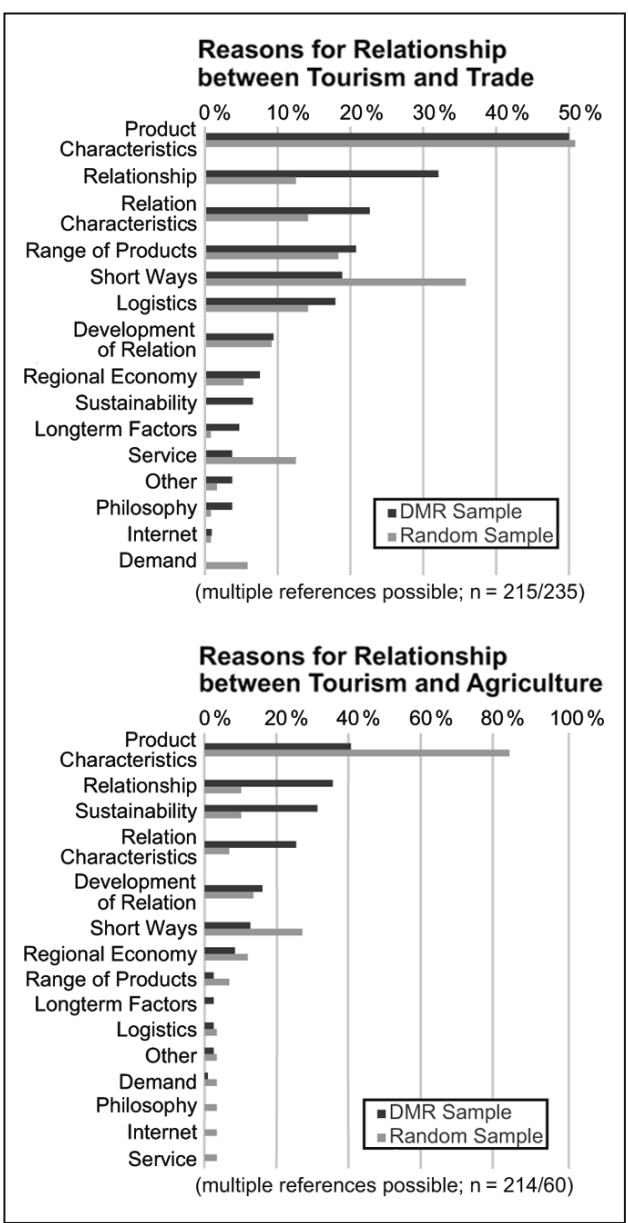

Source: own design and research

On the other hand, in the random sample it can be observed, that more than $35 \%$ of all links are influenced by minimization of supply miles. This high importance in the random sample seems to contrast the idea of the DMR and the BR, which are promoting shorter connections and circles. Above those results, there is a higher rating of sustainability (6.6\%), long-term factors (e.g. contracts, $4.7 \%)$ and philosophy (3.8\%) in the DMR group. The random sample stands out, because they see a higher importance for service and demand by customers.

Moving further to the supply chains between tourism and agriculture we see a different 
weighting of reasons. Still product characteristics are the most important reason for links between lead firms and suppliers, but the random sample puts a much higher emphasize on this factor. In contrast, the DMR sample is more balanced and puts especially higher importance on relationship, relationship characteristics and sustainability. Interestingly, sustainability reaches a high importance in supply chains between tourism and agriculture. Almost $32 \%$ of all supply links from the tourism enterprises of the DMR to agricultural suppliers are influenced by thoughts about a sustainable development. In this category items like landscape conservation, social aspects, organic or BR are aggregated. Again the random sample has a high amplitude on short ways.

\section{Discussion}

In general, rural enterprises within the DMR and random sample of the Rhön Biosphere Reserve alike put a high importance on the idea of local buying. In both groups the answers show similar patterns, but it has been found that "regional economic impact", "relationship to supplier", "marketing", "mutuality" and "philosophy" reached considerably higher percentages in the DMR group. Thus, this basis of decision-making of the enterprises is a successful starting point for the implementation of the guiding principles of the Seville Strategy for sustainable development on a local level and therefore in accordance with the aims of the BR.

Local buying is not an approach which is only found in enterprises of the DMR. The strategy of the BR and DMR to develop an additional marketing effect in terms of a unique selling proposition for the members of the DMR is to be questioned, as most other rural enterprises find local buying important, too. Yet, DMR businesses put a greater relevance to the idea behind it. Only the combination of buying local, good products, a company philosophy and a professional marketing can give these enterprises an advantage in the market. The DMR is helping managers to find the right resource base within the region and gives consultation to improve economic activities. ERMANN (2009) argues that locality in marketing of foods cannot be a value for itself, but it is an organizational concept to achieve certain defined aims like quality and sustainability, thus there needs to be a direct link between goals, implementations and regional impacts.
Besides these reasons for local buying, the study also analyzes the economic impacts of local buying on two levels. First, the study shows that the aim of local buying leads to a tendency to lower percentages of TVA and increase expenditures for supply on the enterprise level. Under these circumstances the idea of directly fostering regional development through local buying of enterprises seems not possible. The interrelations between expenditures and TVA can be explained logically. Enterprises which rely on local products have a smaller range of choices and less suppliers to buy their inputs from, which can lead to a higher dependency and prices. PFISTER (1999) argues from a national account perspective that these structures weaken competition and promote regional monopolies, which lead to inefficient production and even negative ecological effects. In addition, the DMR tries to enhance quality products, which means that inputs are more expensive, so that businesses have higher expenditures for their supply.

Yet, on the contrary, there are diverse opportunities within the idea of local buying. It not only helps to successfully occupy niche/alternative markets but also release marketing effects to customers, thereby helping to generate more turnover. A discrete choice model with tourists in BR shows, that local foods and products are a very important influence factor for consumers within the decision process for tourism destinations (JoB et al. 2013, $111 \mathrm{ff}$.). This fact is becoming even more relevant, as culinary tourism is seen as a potential measure for regional development (VOTH 2011, 223). However, further research is needed to explore the relations between local buying and the internal cost structures in enterprises to fully understand the impact of local buying on regional development.

Secondly, the analysis shows a spatial and structural change of supply chains in enterprises of the DMR. Data reveals that members of the DMR spend more money for supply within the marketing area, leading to higher indirect economic impacts in the region as the leakage rate of supply is not as high. This is in accordance with the overall goal of sustainable development discussed within the Seville Strategy and the assignments of the BR. The frameworks following on subordinate levels can therefore be seen as a first step into a successful implementation.

Additionally there is a restructuring of supply chains towards a greater multifunctionality and 
a lesser dependency on trade. This change to a greater diversity of supply relations can help e.g. tourism to be more self-sustaining by strengthening the local potentials and actors. This greater multifunctionality in terms of supply chains and economic links can lead to the occurrence of "clusters of compatible and mutually reinforcing activities" (VAN DER Ploeg/RENTING 2000, 534), which can have positive tangible and intangible effects on the whole area.

The exploration of management reasons why tourism enterprises select single supply relations to trade and agriculture is understood as a tool to improve the work of the DMR. These stated attributes of connections give a new understanding for changing the supply chains to achieve higher sustainability standards and promote the idea of multifunctionality. The reasons for specific supply chains are very similar in both sample groups, but the weighting is different in some categories. Especially, the reasons concerning the relationship of suppliers are most important for DMR enterprises. This high importance of personal networks and its connections is a fundamental part to re-socialise or re-spatialise supply chains and generate value-laden products. Results can also be seen under the perspective of a new form of regional identity, which is based on a high degree of solidarity between enterprises of the region. These associational interfaces between stakeholders provide a strong basis for sustainable development (MARSDEN et al. 2000, $425 \mathrm{ff}$.). Furthermore, social embeddedness such as reciprocity, principles of social connectivity and trust, which are important for economic transactions and "fundamentally underpin grassroots and 'alternative' initiatives [...]." (SAGE $2003,47 \mathrm{f}$.), is high in the region. It is important as the embeddedness mediates self-interest in place of a concern for the wider common good like community and environmental needs.

From the figures it is clear that sustainability is a rationale for buying certain goods and products in trade, but the share is still small and should be raised. This can be achieved by "education for sustainable development" to the managers and enterprise owners. For this, the BR should demonstrate the modes of action between production processes, ecology and landscape development. This connection is very obvious in agriculture, where changes of production processes have a direct impact on landscape. In many cases the stakeholders do not see the connections between many levels of impacts. If not seen by the busi- ness owners, it is unlikely, that they communicate the concept of the DMR to the customers and thus justify the higher prices of their products. Yet, exactly this would be an essential strategy in order to increase the turnover and thus the proportion of TVA respectively the direct economic impact.

Finally, we see a much greater emphasis in supply in the minimization of supply miles in the random sample. This high importance in the random sample seems to contrast the idea of the DMR and the BR, which are promoting shorter connections and circles. However, these findings are the issue of controversial discussions in literature concerning food miles (e.g. DESROCHERS/ SHimizu 2012; Coley et al. 2009; ERMANN 2009). Leaving aside this controversy, it shows that the concept of local buying can limit the choice of products and thereby lead to an intensification of supply miles. The inclusion of local products into wholesale and trade, as a possibility to improve efficiency, simplify the logistics and to gain new market access, can be seen as a solution. However, if done so, local producers and their products have to compete in trade with conventional products and other local labels on a national or even international market. As a consequence they lose the potential for shifting the production out of their "industrial mode", within which a decreasing proportion of TVA is captured (MARSDEN et al. 2000, 424). Additionally, these products lose a high degree of embedded information when sold via the shelves of trade enterprises as the atmosphere for selling plays a crucial role for local products and food. Besides this, there is also need for an efficient and lowcost logistic system to transport local products, to reduce $\mathrm{CO}_{2}$ emissions and to fulfill the need for service and logistics.

\section{Conclusion}

BÄTZING/ERMANN (2001) name three starting points for the intensification of value chains for their case study, which can be generalized and adopted to the Rhön Biosphere Reserve. First, there is a need for a good and trustful cooperation within the region. The BR concept in general and the regional implementation of the DMR as a support agency aims to develop a network of stakeholders to facilitate sustainable regional development. It follows a bottom-up concept, where the interfaces are the basis to reach aims of common good in terms of sustainability and community development. Second, the region 
needs a labelling scheme to promote local products and to achieve a high quality standard. The DMR in the Rhön Biosphere Reserve has managed to construct a local brand with standardized quality requirements. The DMR members in tourism and food processing are substantially different in their economic thinking than the enterprises of the random group. Relationships between enterprises are seen as a fundamental precondition to follow the rationale of a new way of production, which is disconnected from the industrial mode of production. Third, consumer awareness should be raised to foster appreciation of local products within the population and make a connection between the place of production and consumption. Therefore the enterprises of the DMR can be a suitable multiplier.

In that context, education for sustainable development is a central part of the BR concept. BR should use their competencies not only for education in ecology, but also try to teach a new way of economic thinking, where the impacts of human economic activity are made visible. Therefore, intensive education of local actors (in this case especially the business owners) is a necessary precondition to reach the locals and visitors of the BR as potential consumers through communication, products and services and the label of the DMR. If done so, the economic impact can be raised. A higher indirect effect already exists alongside with the promotion of multifunctionality through the members of the DMR. Therefore the BR concept in Germany may be seen as a good facilitator for regional cooperation, but in total there should be a greater emphasize on sustainable development to better spread the ideas through positive examples. Finally, this call for sustainable development is addressed especially at BR, which are not yet properly adapted to the Seville Strategy.

\section{Notes}

1 The research of this article was elaborated within the project "Regional Economic Impact of Rhön Biosphere Reserve“ (Az 27930), which was kindly supported by Deutsche Bundesstiftung Umwelt. We would like to thank all persons at the foundation and the interviewed businesses, who made this project possible

2 The regional database was compiled of different data sources. First, three databases from the three responsible Chambers of Trade and Commerce were merged. These datasets were validated and extended via a structured and standardized internet research combining regional and sectoral search parameters on business directories.

\section{References}

Amt für das Biosphärenreservat Schaalsee (Hrsg.) (2004): Rahmenkonzept Biosphärenreservat Schaalsee. Kurzfassung - Leitbilder und Ziele. Internet: http://www.schaalsee. de/inhalte/download/ziele.pdf, 4.3.2013.

BAFU (Bundesamt für Umwelt) (2013): Biosphärenreservate. Internet: http://www.bafu.admin.ch/landschaft/00524/ 01672/04756/index.html?lang=de, 21.11.2013.

BARHAm, E. (2003): Translating terroir. The global challenge of French AOC labeling. In: Journal of Rural Studies, (19)1, 127-138.

BÄtzing, W. / ERMANN, U. (2001): Was bleibt in der „Region"? Analyse der regionalen Wirtschaftskreisläufe landwirtschaftlicher Erzeugnise am Beispiel des Landkreises Neumarkt in der Oberpfalz. In: Zeitschrift für Wirtschaftsgeographie, (45)2, 117-133.

Biosfera Val Müstair - Parc Naziunal (2004): Leitbild. Biosfera Val Müstair - Parc Naziunal. Internet: http://www. biosfera.ch/leitbild.pdf, 22.11.2013.

Biosphärenpark Wienerwald Management GmbH (Hrsg.) (2012): Leitbild des Biosphärenpark Wienerwald Managements. Internet: http://www.bpww.at/fileadmin/Redakteure/ BPWW_Leitbild_110325.pdf, 15.11.2013.

BPM Regio Großes Walsertal (Biosphärenparkmanagement der REGIO Großes Walsertal) (Hrsg.) (2011): Leitbild Biosphärenpark Großes Walsertal. Internet: http:/www.grosseswalsertal.at/gemeindeamt/download/222732461_1.pdf, 15.11.2013.

Brenner, L. / JoB, H. (2011): Challenges to actor-oriented environmental governance. Examples from three Mexican biosphere reserves. In: Tijdschrift voor economische en sociale geografie, (103)1, 1-19.

BRR (Biosphärenreservat Rhön) (2012): 258 Mitglieder aus der ganzen Rhön. Internet: http://biosphaerenreservatrhoen.de/de/news/537-258-mitglieder-aus-der-ganzenrhoen-mitgliederversammlung-der-dachmarke-rhoen-tagte, 2.1.2014.

Buller, H. / Morris, C. (2004): Growing goods. The market, the state, and sustainable food production. In: Environment and Planning A, (36)6, 1065-1084.

Coley, D. / Howard, M. / Winter, M. (2009): Local food, food miles and carbon emissions: A comparison of farm shop and mass distribution approaches. In: Food Policy, (34) 2, 150-155

DARNHOFER, I. (2005): Organic farming and rural development. Some evidence from Austria. In: Sociologia Ruralis, (45) $4,308-323$.

Desrochers, P. / Shimizu, H. (2012): The locavore's dilemma. In praise of the 10,000-mile diet. New York.

Destatis (Statistisches Bundesamt) (2011): Produzierendes Gewerbe - Kostenstruktur der Unternehmen des Verarbeitenden Gewerbes sowie des Bergbaus und der Gewinnung von Steinen und Erden. Wiesbaden.

Deutsches MAB-Nationalkomitee (Hrsg.) (2007): Kriterien für Anerkennung und Überprüfung von Biosphärenreservaten der UNESCO in Deutschland. Bonn. 
DRL (Deutscher Rat für Landespflege) (Hrsg.) (2010): Biosphärenreservate sind mehr als Schutzgebiete. Wege in eine nachhaltige Zukunft. Bonn.

ERmanN, U. (2005): Regionalprodukte. Vernetzung und Grenzziehung bei der Regionalisierung von Nahrungsmitteln. Stuttgart.

ERMANN, U. (2009): Ein weiter Weg zu kurzen Wegen? Potentiale und Fallstricke der Stärkung regionaler Wirtschaftskreisläufe durch Regionalvermarktung von Lebensmitteln. In: Popp, H. / Obermaier, G. (Hrsg.): Raumstrukturen und aktuelle Entwicklungsprozesse in Deutschland. Bayreuth, 265-284. (Bayreuther Kontaktstudium Geographie, 5).

Goodman, D. (2004): Rural Europe redux? Reflections on alternative agro-food networks and paradigm change. In: Sociologia Ruralis, (44)1, 3-16.

GREBE, R. / BAUERNSCHMITT, G. (1995): Biosphärenreservat Rhön. Rahmenkonzept für Schutz, Pflege und Entwicklung. Radebeul.

ILBERY, B. / BOWLER, I. (1998): From agricultural productivism to post-productivism. In: Ilbery, B. (Ed.): The geography of rural change. Essex, 57-84.

IlBERY, B. / MAYE, D. (2007): Marketing sustainable food production in Europe. Case study evidence from two Dutch labelling schemes. In: Tijdschrift voor Economische en Sociale Geografie, (98)4, 507-518.

Job, H. / Kraus, F. / Merlin, C. / Woltering, M. (2013): Wirtschaftliche Effekte des Tourismus in Biosphärenreservaten Deutschlands. Bonn / Bad Godesberg. (Naturschutz und Biologische Vielfalt, 134).

KNICKEL, K. (2001): The marketing of Rhöngold milk. An example of the reconfiguration of natural relations with agricultural production and consumption. In: Journal of Environmental Policy \& Planning, (3)2, 123-136.

KNiCKel, K. / Renting, H. (2000): Methodological and conceptual issues in the study of multifunctionality and rural development. In: Sociologia Ruralis (40)4, 512-528.

Kullmann, A. (2007): Regionalvermarktung in den deutschen Biosphärenreservaten. Status Quo-Analyse und Optimierungspotentiale. Bonn/Bad Godesberg. (BfN-Skripten, Band 175).

Lange, S. (2008): Leitfaden zur Prüfung der Eignung eines Gebietes als Biosphärenpark. Studie im Auftrag des Österreichischen MAB-Komitees - Kurzfassung. Internet: http:// www.e-c-o-deutschland.de/downloads/20081231msbr_leitfaden_kurz_low.pdf, 22.11.2013.

Marsden, T. / BAnKs, J. / Bristow, G. (2000): Food supply chain approaches. Exploring their role in rural development. In: Sociologia Ruralis, (40)4, 424-438.

Maschke, J. (2007): Hotelbetriebsvergleich 2005. München. dwif e. V. \& consulting, Sonderreihe 74).

MAYER, M./Job, H. (2014): The economics of protected areas - a European perspective. In: Zeitschrift für Wirtschaftsgeographie, (58)2-3, 73-97.

MegerLe, H. (2013): Landschaftsveränderung durch Raumansprüche erneuerbarer Energien. Aktuelle Entwicklungen und Forschungsperspektiven am Beispiel des Ländlichen Raumes in Baden-Württemberg. In: Gailing, L. / Leibenath, M. (Hrsg.): Neue Energielandschaften - Neue Perspektiven der Landschaftsforschung. Wiesbaden, 145-164. (RaumFragen: Stadt - Region - Landschaft).
Murdoch, J. / MARsden, T. / BAnKs, J. (2000): Quality, nature, and embeddedness. Some theoretical considerations in the context of the food sector. In: Economic Geography, (76)2, 107-125.

NiLES, D. / Roff, R. (2008): Shifting agrifood systems: the contemporary geography of food and agriculture. An introduction. In: GeoJournal, (73)1, 1-10.

Österreichisches MAB-Nationalkomitee (Hrsg.) (2006): Kriterien für Biosphärenparks in Österreich. Wien.

PÄV (Pärkeverordnung) (2007): Verordnung über die Pärke von nationaler Bedeutung vom 7. November 2007 (Updated 1. Januar 2008). Internet: http://www.admin.ch/opc/ de/classified-compilation/20071162/index.html, 1.9.2013.

Pfister, G. (1999): Öko-unlogisch. Regionale Wirtschaftskreisläufe. In: TA-Informationen, (4), 109-126.

VAN DER Ploeg, J. / Renting, H. (2000): Impact and potential. A comparative review of European rural development practices. In: Sociologia Ruralis, (40)4, 529-543.

VAN Der Ploeg, J./ Renting, H. (2004): Behind the 'redux'. A Rejoinder to David Goodman. In: Sociologia Ruralis, (44) 2, 234-242.

VAn der Ploeg, J./Renting, H./Brunori, G. / Knickel, K. / MAnnion, J. / Marsden, T. (2000): Rural development. From practices and policies towards theory. In: Sociologia Ruralis, (40)4, 391-408.

Potter, C. / Burney, J. (2002): Agricultural multifunctionality in the WTO. Legitimate non-trade concern or disguised protectionism? In: Journal of Rural Studies, (18)1, 35-47.

RENTing, H. / MARsden, T. / BANKS, J. (2003): Understanding alternative food networks. Exploring the role of short food supply chains in rural development. In: Environment and Planning A, (35)3, 393-411.

RÜTTER, H. / GUHL, D. / MÜLlER, H. (1996): Wertschöpfer Tourismus. Ein Leitfaden zur Berechnung der touristischen Gesamtnachfrage, Wertschöpfung und Beschäftigung in 13 pragmatischen Schritten. Bern.

SAGE, C. (2003): Social embeddedness and relations of regard. Alternative 'good food' networks in south-west Ireland. In: Journal of Rural Studies, (19), 47-60.

Schamp, E. (2007): Wertschöpfungsketten in Pauschalreisen des Ferntourismus. Zum Problem ihrer Governance. In: Erdkunde, (61)2, 147-160.

SIMS, R. (2009): Food, place and authenticity. Local food and the sustainable tourism experience. In: Journal of Sustainable Tourism, (17)3, 321-336.

Stoll-Kleemann, S. / Job, H. (2008): The relevance of protected areas for biodiversity conservation. An Introduction. In: GAIA, (17)1, 86-89.

Sturgeon, T. (2001): How do we define value chains and production networks? In: IDS Bulletin, (32)3, 9-18.

ToRRES, R. (2002): Toward a better understanding of tourism and agriculture linkages in the Yucatan. Tourist food consumption and preferences. In: Tourism Geographies, (4)3, 282-306.

UNESCO (1996): Biosphere reserves. The Seville Strategy and the statutory framework of the world network. Paris.

UNESCO Biosphäre Entlebuch (о. J.): Die UNESCO Biosphäre Entlebuch Schweiz. Schüpfheim. 
VAn Huylenbroeck, G. / Durand, G. (2003): Multifunctionality. A new paradigm for European agriculture and rural development? Aldershot.

Ventura, F. / Milone, P. (2000): Theory and practice of multi-product farms. Farm butcheries in Umbria. In: Sociologia Ruralis, (40)4, 452-465.
Voтн, A. (2003): Aufwertung regionaltypischer Produkte in Europa durch geographische Herkunftsbezeichnungen. In: Europa Regional, (11)1, 2-11.

Voтн, A. (2011): Apfelweinregionen in Europa. Beispiele der Regionalentwicklung durch Aufwertung eines regionalen Produktes. Vechta. (Vechtaer Studien zur Geographie, Band 2). 